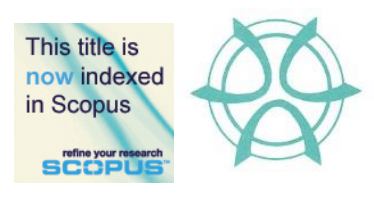

PLANNING MALAYSIA:

Journal of the Malaysian Institute of Planners

VOLUME 16 ISSUE 1 (2018), Page 118 - 129

\title{
THE POWER OF ACCESSIBILITY TO LAND PRICE IN SEMARANG URBAN CORRIDORS, INDONESIA
}

\author{
Anita Ratnasari Rakhmatulloh ${ }^{1}$, Imam Buchori $^{2}$, Wisnu Pradoto ${ }^{3}, \&$ \\ Bambang Riyanto ${ }^{4}$ \\ ${ }^{1}$ Department of Urban and Architecture Engineering \\ ${ }^{2,3}$ Department of Urban and Regional Planning \\ ${ }^{4}$ Department of Civil Engineering \\ DIPONEGORO UNIVERSITY
}

\begin{abstract}
Urban land demand tends to keep increasing as a result of economic and population growths. The high intensity of activity will bring changes to land value. The corridors of Semarang - Ungaran and Semarang - Mranggen have significant differences in land values despite being at relatively the same distance to city centre. Similarly, the rate of land price change in these two corridors are also different. The study aims to examine and prove the effect of distance to city centre toward land price in downtown areas by employing statistical correlation analysis and accessibility calculation. The result reveals that distance to city centre has no longer effect land prices. It was found that the farther from the city centre the land prices decreases gradually but increases at road nodes that connect to the trip generation points such as toll road gate, residential area and commercial area or shopping centre.
\end{abstract}

Keywords: distance to city centre, land price, accessibility 
PLANNING MALAYSIA

Journal of the Malaysia Institute of Planners (2018)

\section{INTRODUCTION}

Urban land demand tends to increase as a result of economic development and population growths. However, the competition for urban land in a perfectly competitive market is determined by the land rent (economic land value) offered. Land use which offers high land rent is likely to win the competition. In the case of housing, the land price is affected by the existence of other surrounding land uses (Xiao, Orford, \& Webster, 2015) such as transport infrastructure, urban configuration and location advantage over other urban land uses.

The existence of transport infrastructure will cause urban growth to be characterized by land value change and land use in along those lines associated with mobility and high degree of accessibility (Ball, Cigdem, Taylor, \& Wood, 2014). Research about interrelation of accessibility change to land value has been undertaken in all main locations in developing countries such as Indonesia, which has demographic and cultural diversity. This research aims to determine and prove whether the proximity to city centre is correlated to land price. Land use changes will lead to the development of urban dynamics beginning with physical, functional, spatial, socioeconomic, as well as demographic changes.

Furthermore, urban accessibility change and housing prices used to estimate the change of location premium on the city structure over time (Gibbon \& Machin (2005).

Changes in land value has also occurred in Semarang City, particularly in the Semarang-Ungaran and Semarang-Mranggen corridors. These two corridors have significant differences in the value land located at equal distance to the city centre. There are also differences in land price changes in both corridors, particularly at main centre of urban activities which has been observed intensively from 2012 to 2016.

Iacono and Levinson (2015) argue that the structure of transport network and accessibility are important determinants of land value and spatial structure of the city. Accessibility is in turned influenced by urban configuration of the city. In the case of Semarang-Ungaran and Semarang-Mranggen corridors, the provision of road infrastructure and urban facilities in both corridors are relatively balanced. This suggests that the differences in land value and land price changes in both corridors were due to spatial structure of the corridors. Thus, how is the urban configuration in these two corridors, what are the differences? This is the main focus of this research.

\section{ACCESSIBILITY}

In general, accessibility is an "opportunity" to move from one activity to another activity or land use. The value of access comes from the ability to reach places and people as determined by land use patterns and transport networks. Without access, the land has only value as far as the natural resources or building structures it has (Levinson \& Istrate, 2012). Accessibility, therefore, is one of the 
Anita Ratnasari Rakhmatulloh, Imam Buchori, Wisnu Pradoto, \& Bambang Riyanto

The Power of Accessibility to Land Price in Semarang Urban Corridors, Indonesia

causes of land attractiveness, and it gives an economic opportunity and causes land value change.

The strong interrelation between urban form and travel pattern is the phenomenon of human activity dynamic (Lingzhu, Alain, \& Yu, 2015). Thus it will create high intensity of human activities, which is a potential to develop other activities with economic benefits. The high intensity of human activities will bring land value changes in those location (Ha, van den Bosch, Quang, \& Zuidgeest, 2011; Salonen \& Toivonen, 2013). In this case, accessibility can encourage the development of socio-economic activities in a region or city. Accessibility can be seen from the dimension of convenience that includes distance and travel time, then it is represented in travel costs which have an implication to production and selling.

Definitions of accessibility involve the destinations, human activities and even travel resistance. Accessibility can be measured by the number of provision of public transportation infrastructure and road network to support the community movement in reaching their destination (Benenson, Martens, Rofe, \& Kwartler, 2011). Wee (2016) explains that the more options available to reach travel destinations to meet activities, as well as the less durable of travel (time, cost, effort) will increase accessibility levels. Accessibility changes will determine land value change, which consequently affects the land use (Khisty \& Lall, 2005), If the change occurred, then the rate of trip generation will change and result in changes throughout the cycle.

People or individuals are more satisfied with the level of accessibility in a region with various land uses and public facilities (Ho, 2011). This shows that network accessibility can describe the bi-centric urban configuration that related to property prices. Network interaction and conventional accessibility can bring positive and negative impact on housing prices at specific locations (Xiao et al., 2015). The high access on land encourages potential improvements to be developed. More development will result in additional movement. In addition, some researchers mentioned issues of land values, rents, and costs within the city, which are considered to be closely related to land use patterns or land configuration (Iacono \& Levinson, 2011).

Accessibility is also a key concept in transportation policy. Public transport investments will increase accessibility in locations where users or residents are directly served by those investments, which is undertaken as part of the public transport network (Jain, Aggarwal, Kumar, Singhal, \& Sharma 2014). Generally, the increased accessibility that occurs as the result in public transport investment is beneficial in raising land price, the process is called increasing land values (Du \& Mulley, 2012). They found that increased accessibility is an important element in rising the land value, which can be obtained by the capital cost recovery of transport investment (benefit cost). 
PLANNING MALAYSIA

Journal of the Malaysia Institute of Planners (2018)

\section{DISTANCE TO CITY CENTRE}

The city centre is the dominant sites of the various metropolitan areas. Iacono and Levinson (2015) state that the city centre or CBD located in the centre of the environment in most cities tend to produce large activities, as well as the level of accessibility generated which cause the high land value. But, areas with stocks of buildings, the scarcity of vacant land, and the existence of surrounding land developments would have no significant change in the level of accessibility, even in the long term. As accessibility has been recognized as crucial term in determining urban land values, the value of non-urban land (exurban) decreases by distance from the city centre due to lower level of accessibility of the nonurban area. Efthymiou and Antoniou (2013) add that price and rent value are also influenced by the proximity to city centre.

Besides accessibility, land value changes are also affected by distance from downtown / CBD and the environmental quality of the area. Thus, in assessing various land values, land location functions, external factors and accessibility are the most important factors. Therefore, urban land reformation will affect different land value between city centre and sub urban due to land market (Lin, Allan, \& Cui, 2015).

\section{MATERIALS AND METHODS}

This research uses positivistic approach with quantitative techniques including accessibility calculation and descriptive statistical analysis. The accessibility indicator was measured by the estimated travel time to the city centre, assessed from the road network as well as the main road. To compute accessibility, access was defined as the distance calculated from the distance to the destination. Travel time is referred to an appropriate accessibility measurement. Corridors of Semarang- Mranggen and Corridor Semarang - Ungaran were chosen to be the study areas since their time series data with periods of 1993, 2004, 2011 and 2015 were available.

\section{DISCUSSION}

The analysis result of 16 sub-districts in Semarang shows the highest level of accessibility located in Southern part of this city because the city centre or CBD, which attracts human movement are located in this area such as government institutions, offices, and trade and commercials areas. This is relevant with theory where downtown area provides the labour market, has high accessibility, with infrastructure provision and others (Du \& Mulley, 2012; Iacono \& Levinson, 2015). Furthermore, the second highest accessibility located in South Semarang and Gajah Mungkur respectively. 
Anita Ratnasari Rakhmatulloh, Imam Buchori, Wisnu Pradoto, \& Bambang Riyanto The Power of Accessibility to Land Price in Semarang Urban Corridors, Indonesia

Table 1: Regional division in analysis of accessibility in Semarang

\begin{tabular}{lll}
\hline ZONE & Activity Centre & Accessibility Value \\
\hline ZONE 1 & Traditional Market & 19,05 \\
ZONE 2 & Traditional Market & 19,15 \\
ZONE 3 & Police Academy & 26,95 \\
ZONE 4 & Central Business District & 33,00 \\
ZONE 5 & University & 22,11 \\
ZONE 6 & Traditional Market & 19,75 \\
ZONE 7 & Modern Market and Mix Use & 20,00 \\
ZONE 8 & Mix Use & 21,32 \\
ZONE 9 & Traditional Market & 21,43 \\
ZONE 10 & Traditional Market & 26,36 \\
ZONE 11 & Business and office functions & 33,45 \\
ZONE 12 & Industry Area & 18,92 \\
ZONE 13 & Traditional Market & 18,64 \\
ZONE 14 & Grocery Mall & 22,66 \\
ZONE 15 & Mix Use & 20,28 \\
ZONE 16 & Toll Gate & 26,08 \\
\hline
\end{tabular}

Figure 1 reveals that high accessibility level was found in West Semarang due to the residential areas and CBD. Urbanization and urban-rural interrelation have given big impact on national economic development, rural transformation and land use transition (Long, Li, Liu, Woods, \& Zou, 2012). The accessibility level in corridor of Semarang-Ungaran is higher than corridor of SemarangMranggen. The existence of Jatingaleh toll gate and Banyumanik Toll Gate was one of the factors that make the accessibility value quite high. They provide easy access to major roads. The location factors have strong influence on urban property markets and accessibility (reachable) since transport infrastructure is a very important factor (Cervero, 2004; Gibbons \& Machin, 2005; Iacono \& Levinson, 2015).

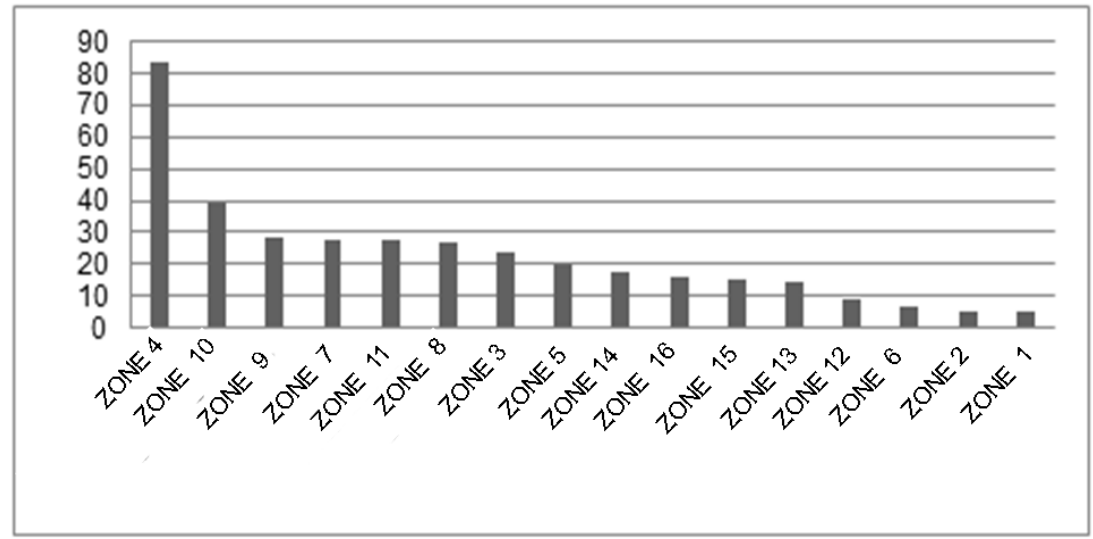

Figure 1: Accessibility level in the 16 sub-districts in Semarang 
PLANNING MALAYSIA

Journal of the Malaysia Institute of Planners (2018)

The second highest accessibility value was found at junction of corridor of Semarang-Ungaran with educational centre such as Diponegoro University. The accessibility values in two corridors were also not much different which both have accessibility between grades 8 to 23 . The public facilities in both corridors can be seen below.
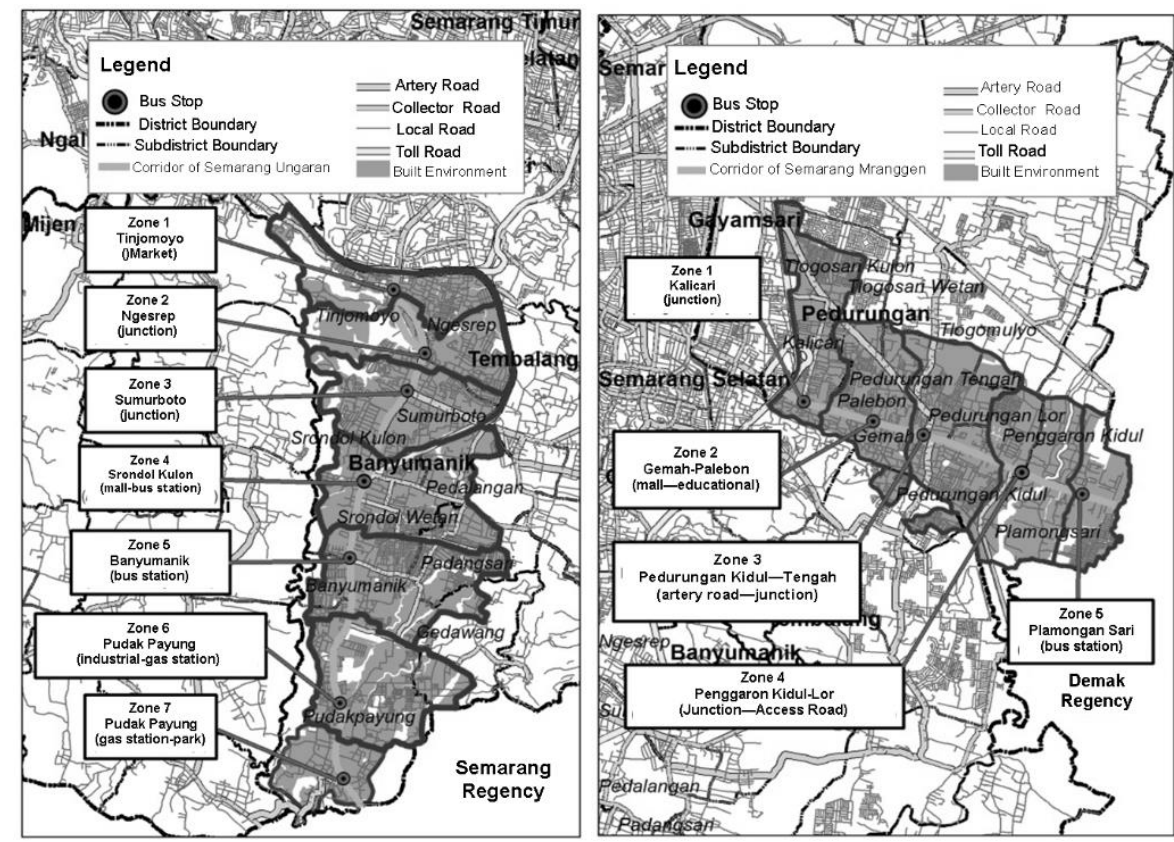

Figure 2: Delineation of service centre in corridors of Semarang-Ungaran and Semarang-Mranggen

Urban facilities such as bus station can attract human movement and generate some activities around the area. The high accessibility due to no road median enables easy access from and to the southern part of Semarang. The three urban regions whose high accessibility belongs to sub service centre located in Regional IV in Corridor of Semarang-Mranggen. Thus, the sub-municipal service centres tend to have high amount of activities with high density of settlements. The large numbers of population in those areas encourages demand for supporting facilities such as trading and commercial facilities (Simmonds, Waddell, \& Wegener, 2013).

The high level of accessibility causes property land prices tend to be decreased due to noise and slightly access of median road (Table 2). Overall, most of zones within corridor of Semarang-Ungaran have higher accessibility compared to the zones in Semarang-Mranggen corridor. However, the land price 
Anita Ratnasari Rakhmatulloh, Imam Buchori, Wisnu Pradoto, \& Bambang Riyanto

The Power of Accessibility to Land Price in Semarang Urban Corridors, Indonesia

in Semarang-Ungaran was from 1.531 USD to 2.041 USD, while property land prices in Semarang-Mranggen was from 714 USD up to 1.531 USD.

Table 2: Accessibility and land price in corridors of Semarang-Mranggen and Semarang-Ungaran

\begin{tabular}{|c|c|c|c|c|}
\hline Zona & & $\begin{array}{l}\text { Total Time } \\
\text { (Minute) }\end{array}$ & $\begin{array}{l}\text { Accessibility } \\
\text { Value }\end{array}$ & $\begin{array}{l}\text { Land } \\
\text { Price } \\
\text { (USD) }\end{array}$ \\
\hline CSM 1 & $\begin{array}{l}\text { Mix Use and access Road to } \\
\text { Residential }\end{array}$ & 261,85 & 18,85 & 1.592 \\
\hline CSM 2 & Grocery Mall and Mix Use & 283,1 & 16,31 & 1.429 \\
\hline CSM 3 & Mix Use and Ring Road & 295,6 & 15,38 & 1.027 \\
\hline CSM 4 & $\begin{array}{l}\text { Mix Use and access Road to } \\
\text { Residential }\end{array}$ & 308,85 & 13,26 & 846 \\
\hline CSM 5 & Bus Station and Mix Use & 379,65 & 8,12 & 432 \\
\hline CSU 1 & Mix Use and access Free Way & 249,4 & 21,12 & 1.680 \\
\hline CSU 2 & $\begin{array}{l}\text { Mix Use and access Road to } \\
\text { Residential }\end{array}$ & 273,33 & 20,36 & 1.635 \\
\hline CSU 3 & $\begin{array}{l}\text { Mix Use and access Road to } \\
\text { University }\end{array}$ & 253,53 & 22,14 & 2.391 \\
\hline CSU 4 & $\begin{array}{l}\text { Grocery Mall and Modern } \\
\text { Market }\end{array}$ & 324,15 & 22,04 & 1.787 \\
\hline CSU 5 & Bus Station and Mix Used & 474,25 & 11,63 & 1.132 \\
\hline CSU 6 & $\begin{array}{l}\text { Mix Use and access Road to } \\
\text { Residential }\end{array}$ & 532,6 & 9,17 & 978 \\
\hline CSU 7 & $\begin{array}{l}\text { Mix Use and access Road to } \\
\text { Residential }\end{array}$ & 658,6 & 8,50 & 749 \\
\hline
\end{tabular}

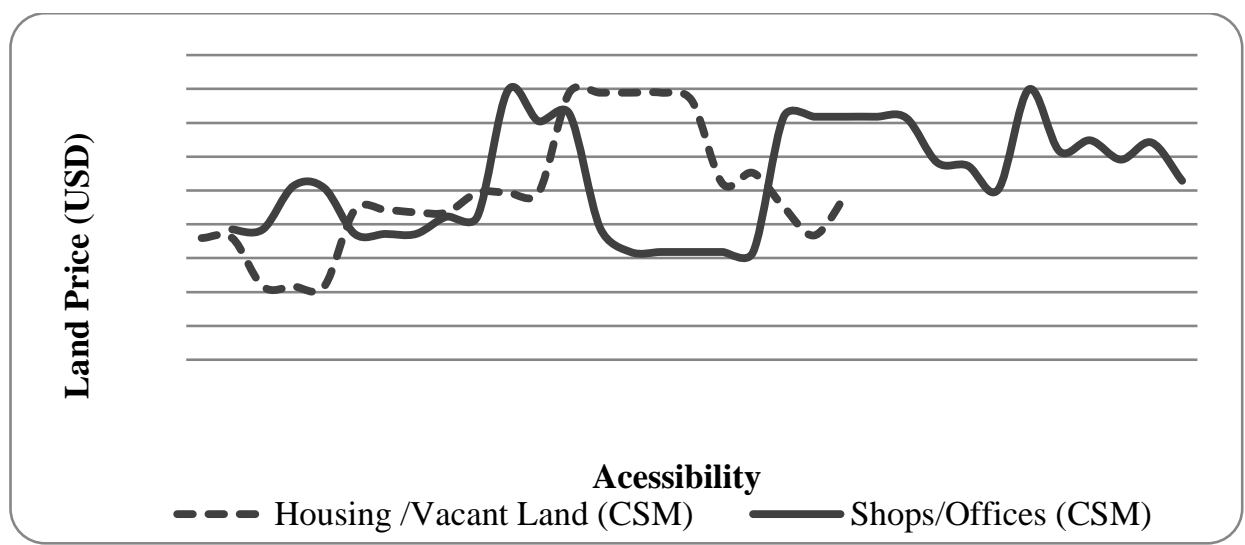




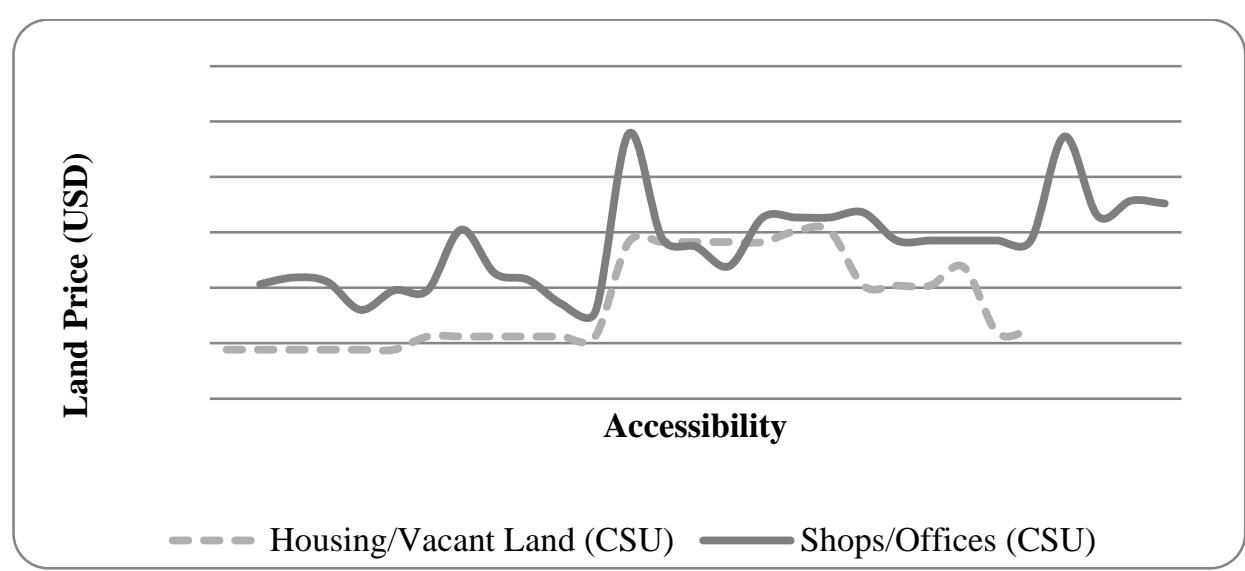

Figure 3: Accessibility Fluctuation toward Land Price

As is presented in Figure 3, the land prices in Semarang-Mranggen tend to steady with slight fluctuation. Furthermore, the corridor of SemarangMranggen also connects to CBD and Semarang hinterlands such as Demak/Grobogan Regency. There is artery road connects eastern and central parts of Semarang to the western parts of Semarang. Increased trip generation will lead to high levels of accessibility and land value. The increasing land value will eventually lead to the activities growth in accordance with the conditions of the region (Yang \& Gakenheimer, 2007).

Figure 4 and Figure 5 show that both corridors have ahd land prices fluctuations on two types of property (shops/offices and vacant land/housing). This fluctuation is in accordance with the established theory that the more distance from downtown, land prices decline significantly but increase again at certain points. These increasing points are located on the radial roads and ring roads as well as crossroads or road intersections between radial roads and ring roads that will create local peaks of land values.

The rate of decrease of land price in Semarang-Mranggen did not differ much between land uses. The function of vacant land declined from Zone 2 to Zone 7 with the increase of land price at certain point in Zone 3 and 5, while for shop/office function has had fluctuation even though land decrease generally from Zone 2 to Zone 8 with improvements in Zones 3, 6 and 5. 
Anita Ratnasari Rakhmatulloh, Imam Buchori, Wisnu Pradoto, \& Bambang Riyanto

The Power of Accessibility to Land Price in Semarang Urban Corridors, Indonesia
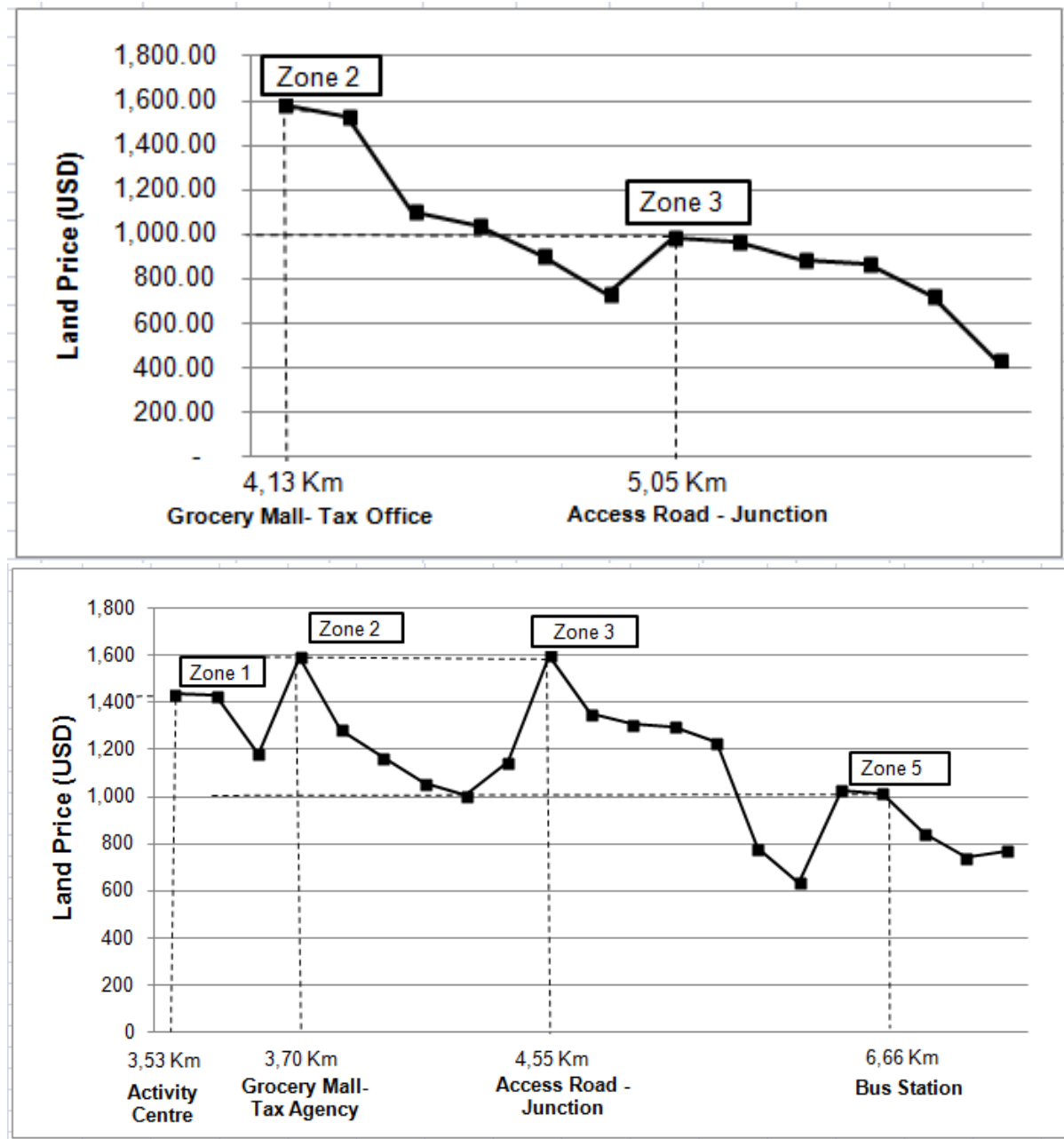

Figure 4: Land price fluctuation in relation to distance to CBD in 8 Zones in corridor of Semarang-Mranggen; (a) Vacant Land/Housing; (b) Shops/Offices 
PLANNING MALAYSIA

Journal of the Malaysia Institute of Planners (2018)

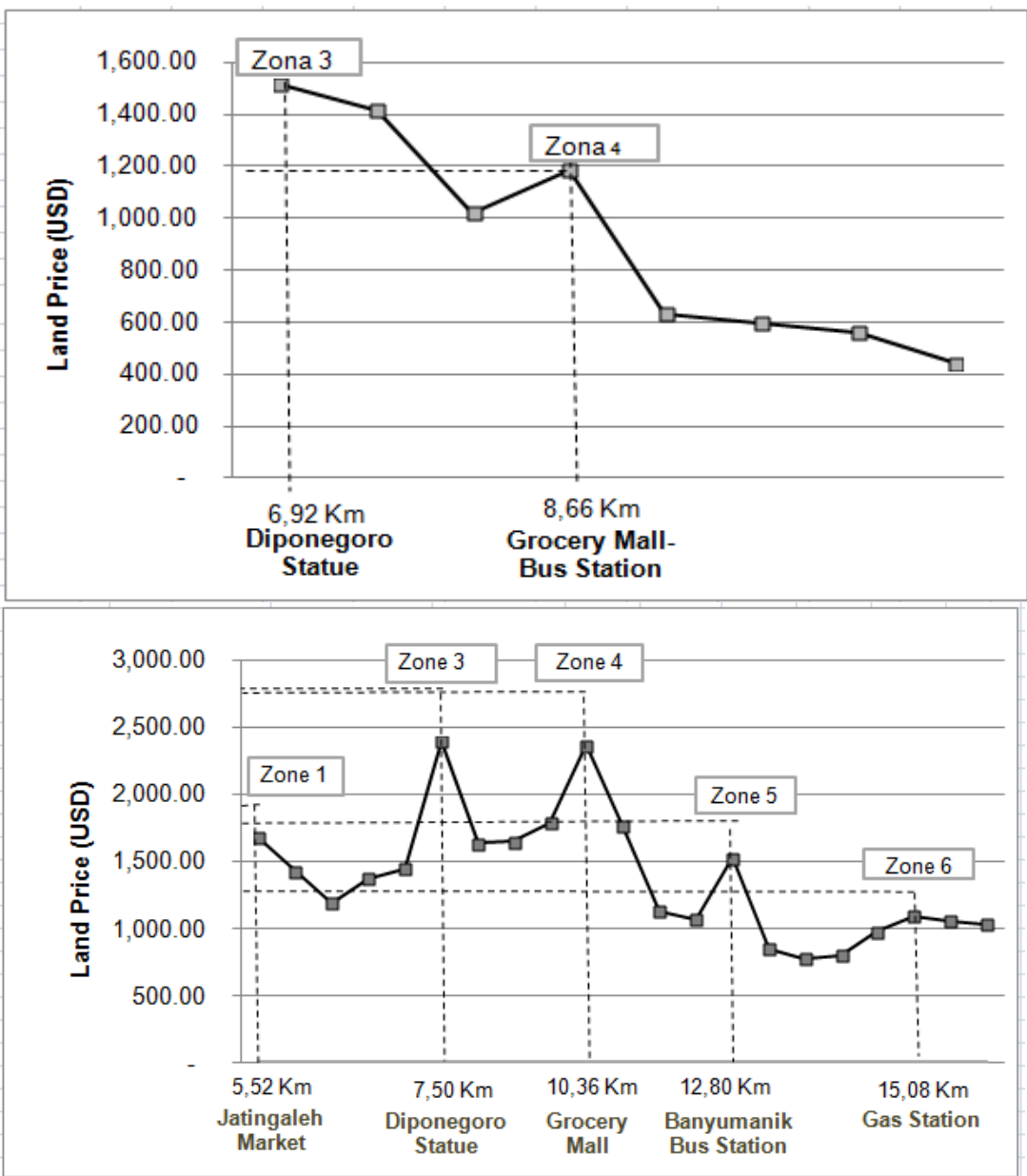

Figure 5: Land price fluctuation in relation to distance to CBD in 8 Zones in corridor of Semarang-Ungaran; (a) Vacant Land/Housing; (b) Shops/Offices

In Semarang-Mranggen, the land price decreased gradually due to the distance away from the city centre. The first point where land price increased again was located in Zone 1, close to city centre. In addition, the point also has proximity to traditional markets (Jatingaleh Market) and Jatingaleh toll gate. The second point of increased land prices located around Zone 2 where there were many activity centres affecting land prices such as Diponegoro University. Land prices increased gradually in Zone 4 due to the activity centre located in toll gate Banyumanik and Grocery Mall. Despite the farthest distance from the city centre, Zone 5 also has quite high land prices due to the influence of activity centres such as Banyumanik terminal and educational facilities. 
Anita Ratnasari Rakhmatulloh, Imam Buchori, Wisnu Pradoto, \& Bambang Riyanto

The Power of Accessibility to Land Price in Semarang Urban Corridors, Indonesia

\section{CONCLUSION}

The bid-rent theory suggests that the closer to the city centre the higher the land rent is. Nevertheless, the results of this study indicate that accessibility also plays a big role in influencing land prices in the study area. The high land price in this study were located at access road to universities and residential area as well as commercial centres. This shows that accessibility strength is greater than distance from the city centre which is a representation of transportation cost. Based on the results, it can be concluded that the peak of increased land price occurred in: the intersection with radial ring, access road to urban settlement, access road to university and shopping centre. The highest point of accessibility located at ring road and toll gate because the construction of highways and toll road network creates accessibility.

\section{REFERENCES}

Ball, M., Cigdem, M., Taylor, E., \& Wood, G. (2014). Urban growth boundaries and their impact on land prices. Environment and Planning A, 46(12), 3010-3026.

Benenson, I., Martens, K., Rofe, Y., \& Kwartler, A. (2011). Public transport versus private car gis-based estimation of accessibility applied to the Tel Aviv metropolitan area. The Annals Regional Science, 47(3), 499-515.

Cervero, R. (2004). Effects of light and commuter rail transit on land prices: Experiences in San Diego County. Journal of the Transportation Research Forum, 43(1), 121-138.

Du, H., \& Mulley, C. 2012. Understanding spatial variation in the impact of accessibility on land value using geographically weighted regression. Journal of Transport and Land Use, 5(2), 46-59.

Efthymiou, D., \& Antoniou, C. (2013). How do transport infrastructure and policies affect house prices and rents? Evidence from Athens, Greece. Transportation Research Part A, 52, 1-22.

Gibbons, S., \& Machin, S. (2005). Valuing rail access using transport innovations. Journal of Urban Economics, 57(1), 148-169.

Ha, P. T. H., van den Bosch, F., Quang, N. N., \& Zuidgeest, M. (2011). Urban form \& accessibility to jobs a comparison of Hanoi \& Randstad metropolitan areas. Journal of Environment \& Urbanization, 2(2), 265-285.

Ho, W. (2011). Land use and transport: How accessibility shape land use (Thesis). University of Hong Kong, Pokfulam, Hong Kong SAR.

Iacono, M. \& Levinson, D. (2015). Accessibility dynamics and location premia: Do land values follow accessibility change? Journal of Urban Studies, 54(2), 364-381.

Iacono, M., \& Levinson, D. (2011). Location, regional accessibility, and price effects: Evidence from home sales in Hennepin County, Minnesota. Transportation Research Record, 22(45), 87-94.

Jain, S., Aggarwal, P., Kumar, P., Singhal, S., \& Sharma, P. 2014. Identifying public preferences using multi-criteria decision making for assessing the shift of urban commuters from private to public transport: A case study of Delhi. Transportation Research Part F: Traffic Psychology and Behaviour, 24, 60-70. 
Khisty, C. J., \& Lall, B. K. (2005). Dasar-dasar Rekayasa Transportasi. Jakarta: Penerbit Erlangga.

Levinson, D. \& Istrate, E. (2012). Access for value: Financing transportation through land value capture. Metropolitan Policy Program at Brookings, 1-15.

Lin, D., Allan, A., \& Cui, J. (2015). The impact of polycentric urban development on commuting behaviour in urban China: Evidence from four sub-centres of Beijing. Habitat International, 50, 195-205.

Lingzhu, Z., Alain, C., \& Yu, Z. (2015). Configuration accessibility study of road and metro network in Shanghai. Natural Science Foundation of China.

Long, H., Li, Y., Liu, Y., Woods, M., \& Zou, J. (2012). Accelerated restructuring in rural China fueled by 'increasing vs. decreasing balance' land-use policy for dealing with hollowed villages. Land Use Policy, 29(1), 11-12.

Salonen, M., \& Toivonen, T. (2013). Modelling travel time in urban networks: comparable measures for private car and public transport. Journal of Transport Geography, 31, 143-153.

Simmonds, D., Waddell, P., \& Wegener, M. (2013). Equilibrium versus dynamics in urban modelling. Environment and Planning B: Planning and Design, 40, 10511070.

Wee, B. v. (2016). Accessible accessibility research challenges. Journal of Transport Geography, 51, 9-16.

Xiao, W. Y., Orford, S., \& Webster, C. J. (2015). Urban configuration, accessibility, and property price: A case study of Cardiff, Wales. Environment and Planning B: Planning and Design, 42, 1-22.

Yang, J., \& Gakenheimer, R. (2007). Assessing the transportation consequences of land use transformation in urban China. Habitat International, 31(3-4), 345-353 